\title{
Religious Exemption and Global History before 1300 - Closing Comments
}

\author{
Julia McClure*
}

Global history has taken many different forms since the sub-field started to expand in the 1980s, but the global turn increasingly resonates across all different branches of history since, as Lynn Hunt explained, historians are all now "writing history in the global era ${ }^{1}{ }^{1}$ The defining feature of our global condition is inequality: $85.3 \%$ of the world's wealth is owned by just $8.6 \%$ of the world's population. ${ }^{2}$ One question to which many practitioners of global history have therefore returned is how this unequal distribution of resources came about: specifically how and why wealth and power came to accumulate in the West slowly from the sixteenth century and sharply from the nineteenth. These questions form the basis of the >Great Divergencer paradigm of global history. ${ }^{3}$ Scholars have challenged the narrative of cultural superiority proposed by Max Weber in the early twentieth century, and instead have looked to various factors including the environment, ${ }^{4}$ the ideology of colonialism, ${ }^{5}$ violence,${ }^{6}$ culture and institutions, ${ }^{7}$ and the rise of the state. ${ }^{8}$ New Institutional Economics (NIE) played an important role in shaping some of these debates, contending that Eurasian divergence was caused by the development of institutions in the west.

This collection of essays offers important insights directly relevant to this debate, highlighting the similarities of the histories of institutions across pre-modern Eurasia, questioning the cultural boundedness of the categories we use to understand the distribution of power and resources within different societies (especially the state), and calling for methodological innovation for a more pluralist understanding of value regimes. It uses the case of religious exemption to challenge teleological narratives of the rise of the state and of secularisation by reminding us not only of the diversity of institutions across Eurasia but also of the symbiotic relationship between institutions, whose analysis calls for a more fluid and dynamic understanding of power. Ultimately, the process of exemption is presented here as a creative force.

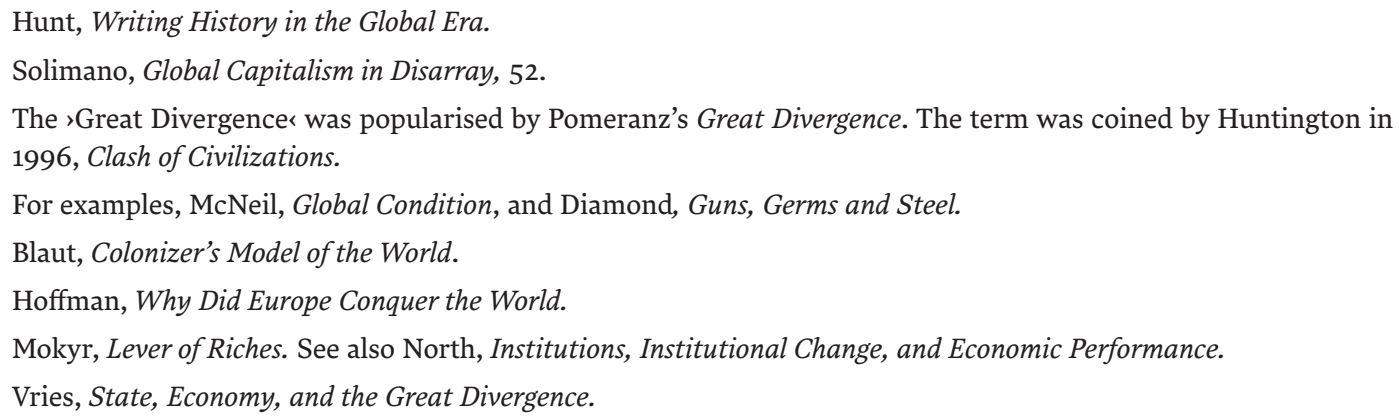


In approaching religious exemption from the state c. 300-1300 in pre-modern Eurasia, the special issue differs from comparisons which tend to emphasise the divergence of institutional traditions. ${ }^{9}$ Under the stewardship of Charles West, the collection is self-consciously styled as a response to the model of pre-modern Eurasian history proposed by Victor Lieberman, that of Strange Parallels. ${ }^{10}$ While Lieberman contended that the long-term developments across Eurasia were driven by state formation, ${ }^{11}$ the essays in this collection focus on the simultaneous processes of the construction of exemptions from these states. The strategy has proved productive on a number of fronts. Firstly, it suggests a new methodology for approaching the history of pre-modern Eurasia. Secondly, it challenges our received categories of power, and our assumptions of the impermeability of secular and religious forms of power. Thirdly, it prompts a more pluralistic understanding of value regimes. Fourthly, and to my mind perhaps most importantly, it signposts new pathways for understanding the historical origins of our current global condition of inequality.

The parameters of this collection were carefully calibrated to maximise the force of the analysis. Going beyond the East-West binary that has often dominated Eurasian histories, this collection questions received geographies and incorporates neglected regions. In addition to studies on Europe and China, four of the eleven case studies focus on South East Asia. Kanad Sinha's contribution (Chapter 3) highlights not only the importance of integrating studies of South East Asia into Eurasian histories, but of challenging all binaries. Sinha begins by questioning the "perceived dichotomy between the settled society (grama) and the forest (aranya) that has dominated early Indian history". The negation of this binary in the first instance is evocative of the rejection of the cultural chauvinism typical of traditional Eurocentric thought which equated sedentary society with civilization and nomadic societies with the wilderness and barbarism.

The focus on the $300-1300$ period is also welcome, since many existing studies of premodern Eurasia have concentrated upon the early modern period. Previous studies of Eurasia in this period have followed the world-systems theory approach which stresses connectivity over correlation. ${ }^{12}$ The quest for correlations is not methodologically the same as comparative approaches, and only one of the essays explicitly constructs a comparative study (Dominic Goodall and Andrew Wareham, Chapter 9), while the rest of the contributions focus on discrete examples. Exploring such examples and emphasising correlation over connectivity is not necessarily limited to painting a pointillist picture of Eurasia, but rather offers the opportunity to highlight certain horizontal continuities. The idea of horizontal continuity has been developed to understand Eurasian history for the early modern period, ${ }^{13}$ but has not yet been explored in relation to the medieval.

9 For more on this also see Hudson and Ana Rodriguez, Diverging Paths?.

10 Lieberman, Strange Parallels Vol. 1, Lieberman, Strange Parallels Vol. 2. These volumes developed ideas from his earlier publications, Lieberman, Beyond Binaries, Re-imagining Eurasia to c. 1830, and Lieberman, Burmese Administrative Cycles.

11 For an overview of this critique see Sreenivasan, A South Asianist's Response to Lieberman's "Strange Parallels".

13 Fletcher, Integrative History. 
Lieberman's model of parallels stretching across Eurasia has of course been heavily contested, especially by early modern histories who advocate connectivity. Most notably Sanjay Subrahmanyam has written that "contrary to what rarea studies implicitly presumes, a good part of the dynamic in early modern history was provided by the interface between the local and regional (which we may term the smicros-level) and the supra-regional, at times even global (what we may term the >macror-level). ${ }^{14}$ Subrahmanyam described the model of connected histories as >orthogonal to Lieberman's model of parallels. ${ }^{15}$ Subrahmanyam presents two key objections to Lieberman's model, arguing that it privileges an overly materialist conception of history, and that he adopts European categories which results in a Weberian teleological narrative of the rise of the state.

Both of these critiques are engaged with in this special issue. While Goodall and Wareham (Chapter 9) provide some support for Lieberman's materialistic thesis, the other contributors to this volume focus on the importance of religion and suggest a more complex relationship between the material and spiritual worlds. Ulrich Pagel compares the implications and practicalities of the renunciants of the ascetic branches of Hinduism and Buddhism in Ancient India and demonstrates how Buddhist ascetic monks tried to benefit from the fiscal exemptions extended to their Hindu Brahmin counterparts for their economic gain, for example, by moving raw cloth without having to paying customs duties. Buddhist monks are presented here as spiritual/economic double agents, consciously trying to manipulate the system of exemption to move mercantile goods while also being allowed to travel between sites of religious devotion. One wonders about the relationship between these value systems, and how Buddhist monks were perceived by their Hindu counterparts. As for the Weberian narrative, such teleologies are explicitly challenged by several of the contributions, which ask us to look at polities more pluralistically. Antonello Palumbo (Chapter 8) does this by questioning the word rexemption itself which, he argues, should be used "with some caution, for as soon as we refer by it to the state's withdrawal from demands imposed on some of its subjects, we are already assuming an absolute power of that state to impose and exact those demands." Instead, Palumbo highlights the different movements and sediments of power in China. In Chapter 12, Thomas Kohl problematizes normative conceptions of the state within Europe, especially the way in which it is interpreted as "a monopoly on violence and an all-encompassing exercise of justice". As Kohl summarises, "the ever increasing number across the world of failed states or of states with weak statehood is a very clear indicator that political entities may take on other forms than a nation state or its medieval precursors". In Chapter 11 Rutger Kramer asks us to think not just about states but also power in a different way, surveying the ways in which religion created spaces of negotiation and how religious figures such as saints could be powerful arbitrators. Kramer presents a world in which "power was pastoral as well as political«, and where the institutional sites of monasteries could bolster »the spiritual foundations of the realm«. 
The volume thereby deepens our understanding of the complexity and diversity of structures and forms of power. As Anne J. Duggan explains in Chapter 6, religious exemption from the state was not a single event but an eco-system of processes around which institutional and legal traditions ossified. Through Duggan's contribution we see the interplay of exemption and the history of Canon Law which contributes to the Western legal tradition. In Chapter $12 \mathrm{Kohl}$ also surveys the judicial dimension of the immunities of clerical communities and considers the practical implications of this, indicating how landscapes of power may be more differentiated than previously presumed. This call for a more a nuanced understanding of the distribution of power is echoed by Kriston Rennie, suggesting that »exemption means closeness to the centre, not distance from it«. Rennie argues that "from the origins of a western monastic tradition, exemption created an administrative, spiritual, and judicial bond between a monastery and its diocesan bishop." The impression left is that of a polycentric network shaped by a more dynamic and elastic notion of power.

The volume reflects (but is not confined to) the social anthropological turn in global history. It not only interrogates our historic understanding of resource distribution but also the plurality of value systems around the world. Mario Poceski evokes a sense of this plurality as he observes that »the central monastic ideals, especially the emphasis on detachment and transcendence, were largely inimical to the pursuit of power and the accumulation of wealth". Rennie (Chapter 5) indicated how the meaning of values could change as they moved across value regimes (to use Arjun Appadurai's term): "the commodity on offer (i.e., protection) served to re-define the exemption's central character and inherent use-value." In a set of essays where religious exemption from the state ceases to seem exceptional, Sinha reminds us that entering these ascetic institutions (in this case the hermitage rather than the monastery) was itself a counter-cultural renunciation of the normative values of the society in question.

Together, this special issue uses analyses of one specific issue to call on us to restructure our thinking of premodern Eurasia and the making of the modern world. It negotiates an innovative critique of secularization narratives by, as Judith Green (Chapter 13) summarises, questioning the durability of the stwo spheres model, of the distinctness of the spiritual and secular worlds. This is a key theme throughout the volume. R. I. Moore sets the agenda with his essay >Treasures in Heaven<, which reminds us of the entanglement of the spiritual and secular worlds, of the religious dimensions of economic transactions. In Chapter 4, Poceski highlights the need to "problematize the basic religious-secular dichotomy, especially the supposed opposition that pitted the church (here represented by Buddhism) against the secular state (represented by the various Chinese empires that rose and fell during the medieval period)."Significantly, Uriel Simonsohn's (Chapter 10) contribution transcends the institutional level in search of individual actors. The result is a picture of individual agents driven by competing but not mutually exclusive value systems capable of manipulating the institutional structures with which they interact. The insight we gain from this is that just as the model of secular and religious power carved into discrete units does not hold at the institutional level, nor does it at the level of the individual. This highlights the fluidity between the strictly socio-religious and the strictly economic. The impression from this glance at Eurasia in the Middle Ages is that reality was far more malleable than the neat models would suggest. Yet such a conclusion also warrants caution, since the malleable material of the Middle Ages has been shaped into the foundations of many visions of the world. 
In the opening to this volume, R. I. Moore suggests that the suniversal phenomena of exemption across Eurasia, what we might think of as an example of horizontal continuity, indicates that the systematisation of the nature and use of religious exemption between the tenth and the thirteenth centuries CE were central to transformations across Eurasia in that period - the threshold that Moore has elsewhere referred to as the >Great Diversification<. ${ }^{16}$ Moore also contends that the demise of the system of religious exemption from the state which occurred in Britain with the dissolution of the monasteries was also transformative since it unlocked vast amounts of wealth which fuelled the rise of the gentry in Britain. To depict this story Moore uses an example from Jane Austen, a strategy also recently deployed by Thomas Piketty in his monumental study of the historical causes and trajectory of global inequality. ${ }^{17}$ Moore links his analysis to debates on the Great Divergence, observing that »in the story of /Why Europe? among the civilizations of the world that made the breakthrough to industrialism, the formation of the modern state has been seen almost unanimously as a necessary condition of economic modernisation, and the removal of religious exemption as a necessary condition of the formation of the modern state«, and contends that consequently the complex story of exemption demands more attention, not least since it is still with us today. This suggests that the vertical continuities in processes of exception and exemption may contribute to our excavation of the historical processes of our current condition of global inequality. 


\section{References}

Abu-Lughod, Janet, Before European Hegemony: The World System A.D. 1250-1350 (Oxford, 1991).

Blaut, James Morris, The Colonizer's Model of the World: Geographic Diffusionism and Eurocentric History (New York, 1993).

Diamond, Jared, Guns, Germs and Steel: A Short History of Everybody for the Last 13,00o Years (London, 1998).

Fletcher, Joseph, Integrative History: Parallels, and Interconnections in the Early Modern Period, 1500-180o, Journal of Turkish Studies, 9 (1985) 37-57.

Hoffman, Phillip, Why Did Europe Conquer the World (Princeton, 2016).

Hudson, John, and Rodriguez, Ana, Diverging Paths? The Shape of Power and Institutions in Medieval Christendom and Islam (Leiden, 2014).

Hunt, Lynn, Writing History in the Global Era (New York, 2014).

Huntington, Samuel, The Clash of Civilizations and the Remaking of World Order (London, 1996).

Lieberman, Victor, Strange Parallels Vol. 1, Southeast Asia in Global Context, c.80o-1830: Integration on the Mainland (Cambridge, 2003).

Lieberman, Victor, Strange Parallels Vol. 2, Mainland Mirrors: Europe, Japan, China, South Asia, and the Islands: Southeast Asia in Global Context, c.80o-1830 (Cambridge, 2010).

Lieberman, Victor, Beyond Binaries, Re-imagining Eurasia to c. 1830 (Michigan, 1999).

Lieberman, Victor, Burmese Administrative Cycles (Princeton, 1984).

Mokyr, Joel, The Lever of Riches: Technological Creativity and Economic Progress (Oxford, 1990).

Moore, R. I., Medieval Europe in World History, in: Carol Lansing and Edward D. English (eds.), A Companion to the Medieval World (Oxford, 2012) 563-581.

McNeil, William H. The Global Condition: Conquerors, Catastrophes and Community (Princeton, 1980).

North, Douglas C., Institutions, Institutional Change, and Economic Performance (Cambridge, 1991).

Piketty, Thomas, Capital in the Twenty First Century (Harvard, 2014).

Pomeranz, Kenneth, Great Divergence: China, Europe, and the Making of the Modern World Economy (Princeton, 2001).

Solimano, Andres, Global Capitalism in Disarray: Inequality, Debt, and Austerity (Oxford, 2016).

Sreenivasan, Ramya, A South Asianist's Response to Lieberman's "Strange Parallels", The Journal of Asian Studies, 70/4 (2011) 983 -993.

Subrahmanyam, Sanjay, Connected Histories: Notes Towards a Reconfiguration of Early Modern Eurasia, Modern Asian Studies, 31/3 (1997) 735-762.

Vries, Peer, State, Economy, and the Great Divergence (London, 2015). 